\title{
ESCHERICHIA COLI CELL INACTIVATION BY SUPEROXIDE ANION AND HYDROGEN PEROXIDE
}

\author{
KEN-ICHI NISHIDA, MASAMICHI TAKAGI, AND KEIJI YANO \\ Laboratory of Radiation Microbiology, Department of Agricultural Chemistry, \\ The University of Tokyo, Bunkyo-ku, Tokyo
}

(Received June 19, 1981)

\begin{abstract}
The effect of superoxide anion $\left(\mathrm{O}_{2}^{-}\right)$on killing of cells was studied. $E$. coli was killed by a non-enzymatical $\mathrm{O}_{2}{ }^{-}$-generating system, i.e. a phenazine methosulfate (PMS)-NADH system. Both polA and recA repairdeficient mutants were more sensitive to $\mathrm{O}_{2}{ }^{-}$than wild type cells. Furthermore, using the polA mutant strain, it was clearly shown that incubation in growing medium increased survival, indicating the involvement of a rec-dependent repair system. It was concluded that the direct cause of cell death induced by $\mathrm{O}_{2}{ }^{-}$was DNA damage. When a scavenger of the active oxygen, such as superoxide dismutase (SOD) or catalase, was present in the reaction buffer during $\mathrm{O}_{2}{ }^{-}$treatment, the survival of cells increased. Of especial note, cells were completely protected by addition of catalase. It was suggested that $\mathrm{H}_{2} \mathrm{O}_{2}$ produced from $\mathrm{O}_{2}{ }^{-}$and $\mathrm{H}_{2} \mathrm{O}$ was a molecule more toxic to $E$. coli cells than the $\mathrm{O}_{2}{ }^{-}$itself in this system. When SOD and catalase were induced inside cells by adding methylviologen in the medium, a protective effect against $\mathrm{O}_{2}{ }^{-}$appeared. Cells treated with methyl-viologen were also resistant, although slightly, to aerobic $\gamma$-ray irradiation, suggesting that the scavenger of active oxygen in cells was partly responsible for protection against $\gamma$-ray irradiation. It is deduced that $\mathrm{O}_{2}{ }^{-}$and/or $\mathrm{H}_{2} \mathrm{O}_{2}$ generated in cells may be one of the causes of cell damage by aerobic $\gamma$-ray irradiation.
\end{abstract}

The presence of oxygen during irradiation with $\gamma$-rays or X-rays enhances the lethality to living organisms. Such a phenomenon, called the oxygen effect, has been suggested to be caused by the active oxygen molecules such as $\mathrm{O}_{2}{ }^{-}, \mathrm{OH}^{*}$, $\mathrm{H}_{2} \mathrm{O}_{2},{ }^{1} \mathrm{O}_{2}$, which are known to be generated in $\mathrm{H}_{2} \mathrm{O}$ when irradiated under the aerobical condition. There are many reports which indicate that the active oxygen molecules play toxic roles in biological systems (1-3). Concerning the cause of the oxygen effect, however, it is unclear which species of the active oxygen molecule is responsible for the enhancement of the cell damage. Involvement of $\mathrm{O}_{2}{ }^{-}$ 
in the oxygen effect has been studied by several workers (4-9). When cells were irradiated in the presence of oxygen, addition of superoxide dismutase (SOD, EC 1.15.1.1) or catalase (EC 1.11.1.6) into the cell suspension reduced lethality to cells. Furthermore, cells which had high levels of SOD, especially manganese$\mathrm{SOD}$, gained resistance towards $\mathrm{O}_{2}{ }^{-}$generated intracellularly $(10,11)$.

The present paper describes lethality to $E$. coli $\mathrm{K}-12$ induced by $\mathrm{O}_{2}{ }^{-}$which was generated extracellularly by the chemical reaction between phenazine methosulfate (PMS) and NADH in the presence of oxygen. The results obtained here indicate that the direct cause of cell death in this system was DNA damage and that $\mathrm{H}_{2} \mathrm{O}_{2}$ produced from $\mathrm{O}_{2}{ }^{-}$and $\mathrm{H}_{2} \mathrm{O}$ was more toxic than $\mathrm{O}_{2}{ }^{-}$itself.

\section{MATERIALS AND METHODS}

Bacterial strains. E. coli $\mathrm{K}-12 \mathrm{~W} 3623\left(\mathrm{gal}\right.$, his, trp, $\left.\mathrm{Sm}^{\mathrm{r}}\right)$ was kindly supplied by Dr. Ozeki, The University of Kyoto. E. coli K-12 YK344 polA1 (thy, rel-1, $\mathrm{Sm}^{\mathrm{r}}$ ) and KL16-99 $\mathrm{rec} A$ (thi, rel-1) were supplied by Dr. Yoda, The University of Tokyo.

Growth conditions and $\mathrm{O}_{2}^{-}$generation system. Cells were grown at $37^{\circ}$ in a TSY medium composed of $3 \%$ trypticase soy broth and $0.5 \%$ yeast extract (Difco Lab., Detroit, USA) supplemented with thymidine $(40 \mu \mathrm{g} / \mathrm{ml})$. Cells at the late logarithmic phase were harvested by centrifugation and washed twice with $50 \mathrm{~mm}$ potassium phosphate buffer ( $\mathrm{pH} 7.8$ ) and resuspended in the same buffer. To the cell suspension in the same buffer $\left(2-5 \times 10^{5} \mathrm{cells} / \mathrm{ml}\right)$, PMS was added to give a final concentration of $4 \mu \mathrm{g} / \mathrm{ml}$ and the reaction was started by addition of NADH (final concentration $0.067-0.67 \mathrm{~mm}$ ). The reaction mixture was incubated at $25^{\circ}$ for $10 \mathrm{~min}$, cells were diluted to $2-5 \times 10^{3}$ cells $/ \mathrm{ml}$ with the saline buffer $(0.14 \mathrm{M}$ $\mathrm{NaCl}, 10 \mathrm{~mm}$ sodium phosphate buffer, $\mathrm{pH} 7.1$ ) or M9 minimal medium with $0.4 \%$ glucose, $0.2 \%$ casamino acids were supplemented with thymine (final concentration was $40 \mu \mathrm{g} / \mathrm{ml}$ ) and further incubated at $25^{\circ}$ or $0^{\circ}$ for $50 \mathrm{~min}$. The cell suspension was plated on nutrient agar plates and incubated for $24 \mathrm{hr}$ at $37^{\circ}$ for colony formation.

Cell extracts and enzyme assay. Cells ( $50 \mathrm{ml}$ culture) were harvested, washed twice with $50 \mathrm{~mm}$ potassium phosphate buffer ( $\mathrm{pH} 7.0$ ), sonicated in $50 \mathrm{~mm}$ potassium phosphate buffer ( $\mathrm{pH} 7.8)$ plus EDTA $(0.1 \mathrm{~mm})$ for $5 \mathrm{~min}$ with a Branson sonifier and clarified by centrifugation at $14,000 \mathrm{rpm}, 60 \mathrm{~min}$. The supernatant was dialyzed against the same buffer for $18 \mathrm{hr}$. SOD activity was determined by the method of ASADA et al. (12), which is a modified method of MCCORD and FRIDOvich (13). Catalase was assayed by the method of BEERS and Sizer (14) and its specific activity was determined by the method of Kurono and HoriKoshi (15). Protein was measured by the method of Lowry et al. (16) using pure bovine serum albumin as a standard.

Induction of SOD and catalase by methyl-viologen. Wild type E. coli W3623 
cells were grown in TSY medium, and at the early logarithmic phase, methylviologen (Tokyo Kasei Co.) was added to a final concentration of $1 \mathrm{~mm}$. Then cells were further grown for $1 \mathrm{hr}$ at $37^{\circ}$ to induce the enzymes. The cells were harvested and washed before further use.

Hydrogen peroxide treatment of cells. Cells grown under the same condition described above were suspended in $50 \mathrm{~mm}$ potassium phosphate buffer $(\mathrm{pH} \mathrm{7.8)}$ to $2-5 \times 10^{5}$ cells $/ \mathrm{ml}$. $\quad \mathrm{H}_{2} \mathrm{O}_{2}$ was added to the cell suspension to a final concentration of $2 \mathrm{~mm}$ followed by incubation for $10 \mathrm{~min}$ at $25^{\circ}$. Cells were then diluted to $2-5 \times 10^{3}$ cells $/ \mathrm{ml}$ with saline buffer and further incubated for $50 \mathrm{~min}$ at $25^{\circ}$.

$\gamma$-Ray irradiation. Irradiation of the cell suspension was performed at $0^{\circ}$ with a ${ }^{137}$ Cs irradiatior of The Research Center of Nuclear Science and Technology at The University of Tokyo. Dose rate was $9.0 \times 10^{4} \mathrm{rad} / \mathrm{hr}$.

\section{RESULTS}

\section{Detection of $\mathrm{O}_{2}{ }^{-}$in PMS-NADH system}

The amount of $\mathrm{O}_{2}^{-}$generated in the PMS-NADH system was determined by measuring the reduction of nitroblue tetrazorium (NBT), as described by NISHIKIMI et al. (17). Figure 1 shows the rate of the reduction of NBT determined by reading at $540 \mathrm{~nm}$. It is shown that $\mathrm{O}_{2}{ }^{-}$is generated in proportion to the amount of NADH added. We expected that the lethality to cells in this system might vary with the amount of PMS added. So, in this study, we employed the same amount of PMS as FRIED used (18), that is, $4 \mu \mathrm{g} / \mathrm{ml}$. Under this condition, the reaction of $\mathrm{O}_{2}{ }^{-}$generation terminated in $10 \mathrm{~min}$ at room temperature. This method seemed to be better than the xanthine-xanthine oxidase system in controlling the amount

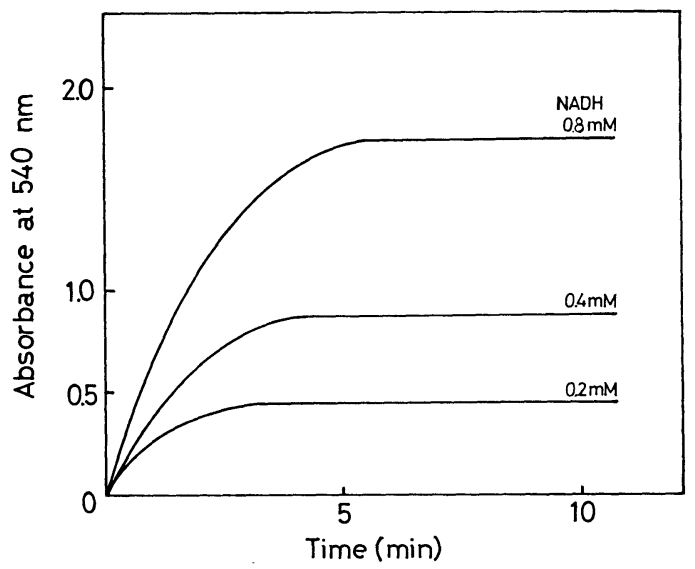

Fig. 1. $\mathrm{O}_{2}{ }^{-}$-Generation in PMS-NADH system.

The reaction mixture contained NBT $(0.33 \mathrm{mg} / \mathrm{ml})$. PMS $(3.3 \mathrm{mg} / \mathrm{ml})$, EDTA $(1 \mathrm{~mm})$ and various amounts of $\mathrm{NADH}$. Reaction for $\mathrm{O}_{2}{ }^{-}$-generation was carried out at $25^{\circ}$ and the increase of absorbance at $540 \mathrm{~nm}$ was measured. 


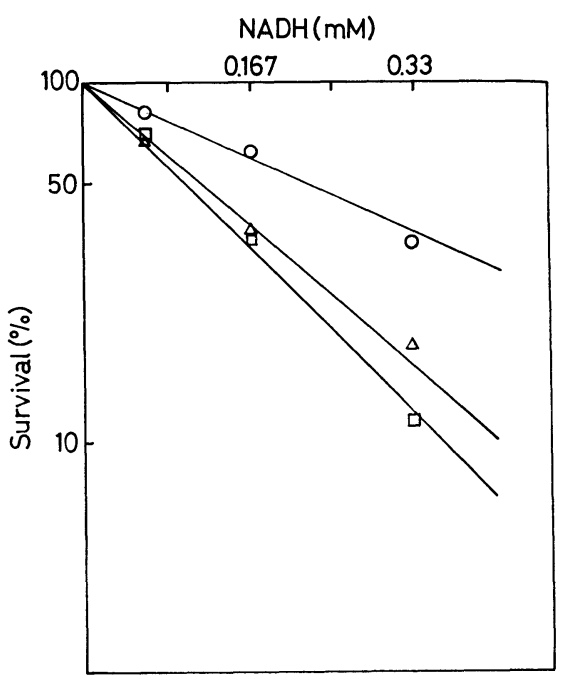

Fig. 2.

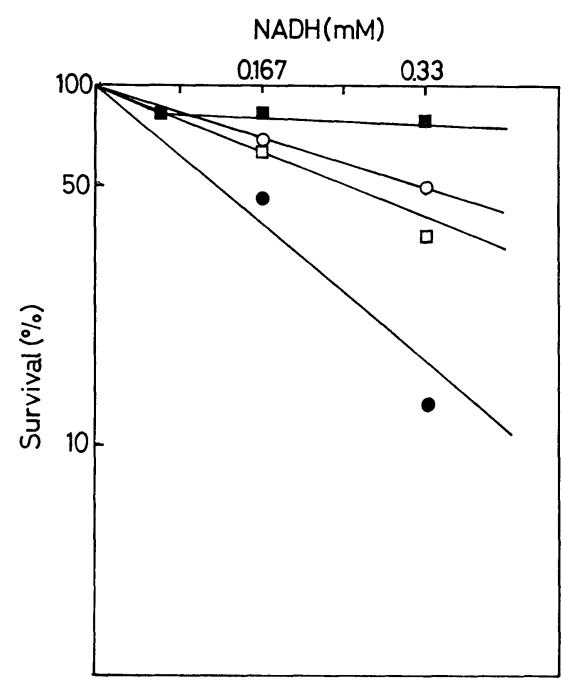

Fig. 3 .

Fig. 2. Effect of $\mathrm{O}_{2}^{-}$on survival of three strains of E. coli.

Cells at the logarithmic phase were exposed to $\mathrm{O}_{2}{ }^{-}$at $25^{\circ}$. After being treated with $\mathrm{O}_{2}{ }^{-}$, cells were diluted with saline buffer and further incubated for $50 \mathrm{~min}$ at $25^{\circ}$. $O$, W3623 wild type strain; $\triangle$, KL16-99 rec $A$ strain; $\square$, YK344 polA strain.

Fig. 3. Effect of $\mathrm{O}_{2}{ }^{-}$on survival of E. coli YK344 polA strain. After the treatment with $\mathrm{O}_{2}-$ as described in the legend for Fig. 2, cells were diluted with saline buffer or M9 minimal medium and further incubated at $25^{\circ}$ or $0^{\circ}$ for $50 \mathrm{~min}$. $\bullet, 25^{\circ}$ in saline buffer; $\mathbf{\square}$, $25^{\circ}$ in $\mathrm{M} 9$ medium; $O, 0^{\circ}$ in saline buffer; $\square, 0$ in $\mathrm{M} 9$ medium.

of $\mathrm{O}_{2}^{-}$generated.

Effect of $\mathrm{O}_{2}{ }^{-}$on survival of cells

Figure 2 shows the survival curves of three strains, E. coli K-12 W3623 wild type, YK344 polAl and KL16-99 recA. The lethalities of the three strains followed single hit kinetics. Both polAl and recA cells were about two-fold more sensitive to $\mathrm{O}_{2}^{-}$than wild type cells. These lethal effects were clearly detected only when the cells were at the logarithmic phase. Neither was the effect of medium negligible. The sensitivity of cells grown in TSY medium was about three-fold higher than cells grown in L-broth or nutrient broth (data not shown). Therefore, it is concluded that the sensitivity of cells to $\mathrm{O}_{2}{ }^{-}$depends not only on their genetic background for DNA repair, but also on their physiological and growing conditions.

\section{Pepair induction in polA1 cells}

It is known that there are three distinct types of repair mechanisms in $E$. coli after irradiation with X-ray aerobically, as reported by Town et al. $(19,20)$. Type I repair occurs rapidly. Type II repair, which requires DNA polymerase I function, occurs immediately in buffer. On the other hand, rec gene-dependent repair, 
called type III repair, requires growth medium and incubation, indicating that protein synthesis and DNA replication are needed for the occurrence of this repair process.

As it was suggested that the damage of cells by $\mathrm{O}_{2}{ }^{-}$in our system was due to the lesion of DNA chains (Fig. 2), we examined which type of repair mechanism described above was involved in the DNA damage. Cell suspensions after $\mathrm{O}_{2}{ }^{-}$ treatment were diluted with saline buffer or M9 medium and incubated for $50 \mathrm{~min}$ under different conditions as described in Materials and Methods. Figure 3 shows the survival of YK344 polA1 under four distinct conditions. Cells incubated in M9 medium at $25^{\circ}$ showed higher survival than cells under the other conditions. Cells incubated at $0^{\circ}$ in saline buffer and M9 medium had similar sensitivities. From these results, together with the results shown in Fig. 2, it is concluded that the cause of the lethality to $E$. coli induced by the $\mathrm{O}_{2}{ }^{-}$generating system is related to DNA damage which is partly repairable by type III or rec gene-dependent repair.

Protection of cells from killing effect by addition of SOD or catalase

SOD or catalase was added to the reaction buffer before $\mathrm{O}_{2}{ }^{-}$generation. Figure 4 shows that addition of SOD had a protective effect against cell killing. However, the recovery was at most $50 \%$ and did not extend further. On the other hand, added catalase protected cells to a level of almost $100 \%$. SOD and catalase inactivated by heating at $95^{\circ}$ for $5 \mathrm{~min}$ did not protect cells from the lethal effect. These results show that not only $\mathrm{O}_{2}{ }^{-}$but also $\mathrm{H}_{2} \mathrm{O}_{2}$ participates in the cell killing process, the latter being more toxic than the former.

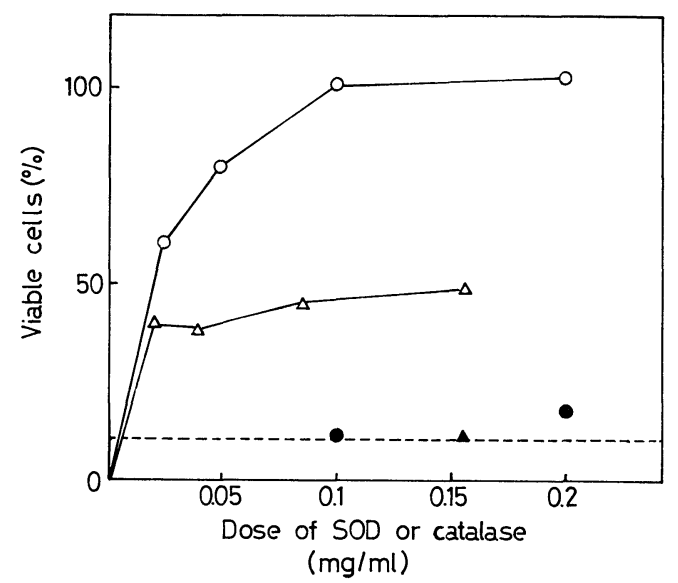

Fig. 4. Protective effect of SOD or catalase against $\mathrm{O}_{2}{ }^{-}$.

SOD or catalase was added to the reaction mixture prior to NADH addition, $2 \mathrm{~mm}$ $\mathrm{NADH}$ then being added to the reaction mixture. The strain used for this experiment was YK344 polA. $\triangle$, SOD; $\bigcirc$, catalase; $\Delta$, heated SOD; $\bullet$, heated catalase; ---, an average level of viable cell number when the concentration of NADH was $0.33 \mathrm{~mm}$. 
Effect of intracellular enzyme induction by methyl-viologen

Methyl-viologen (1,1-dimethyl-4-bipyridinium dichloride), is known to increase intracellular $\mathrm{O}_{2}^{-}$production (21) when it is added to the incubation medium. Escherichia coli contains three kinds of SOD; a Mn-, a Fe- and a both metalscontaining SOD (22). The level of SOD, especially a Mn-containing SOD, is increased by adding methyl-viologen (11), suggesting that this SOD acts as a protector against the toxicity of $\mathrm{O}_{2}^{-}$generated in cells. Table 1 shows our experimental results of enzyme induction by methyl-viologen which was added to the medium containing early logarithmic phase cells. Incubation was continued for $1 \mathrm{hr}$ at $37^{\circ}$. During this time, enzymes were induced and their levels increased with the time of incubation. Cells grown in a medium in which methyl-viologen was added had 2 times as strong activities of SOD and catalase as cells grown without methyl-viologen. As shown in Fig. 5, cells which had been treated with methylviologen had great resistance to $\mathrm{O}_{2}{ }^{-}$. This result indicates that the increase of SOD or catalase inside cells may cause resistance to $\mathrm{O}_{2}{ }^{-}$generated extracellularly.

Table 1. The effect of methyl-viologen on specific activities of SOD and catalase in E. coli cell extract.

\begin{tabular}{lcc} 
& \multicolumn{1}{c}{ Specific activity (unit/mg protein) } \\
\hline Methyl-viologen-treated cells & SOD & Catalase \\
Non-treated cells & 47.9 & 5.4 \\
\hline
\end{tabular}

Methyl-viologen was added to the medium of early logarithmic phase culture of E. coli (final $1 \mathrm{~mm}$ ). After incubation for $1 \mathrm{hr}$, cells were collected, the crude extract was prepared and two enzyme activities were assayed.

For the calculation of the specific activity of SOD and catalase, see references 12 and 15 , respectively.

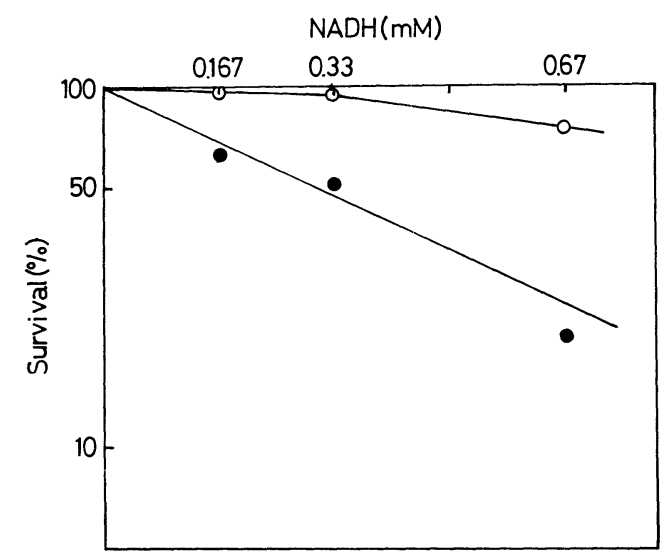

Fig. 5. Effect of methyl-viologen on survival of E. coli W3623 against $\mathrm{O}_{2}{ }^{-}$.

Conditions of growth are as described in the legend for Fig. 4. $\bigcirc$, methyl-viologen treated cells; $\boldsymbol{\bullet}$, control cells. 


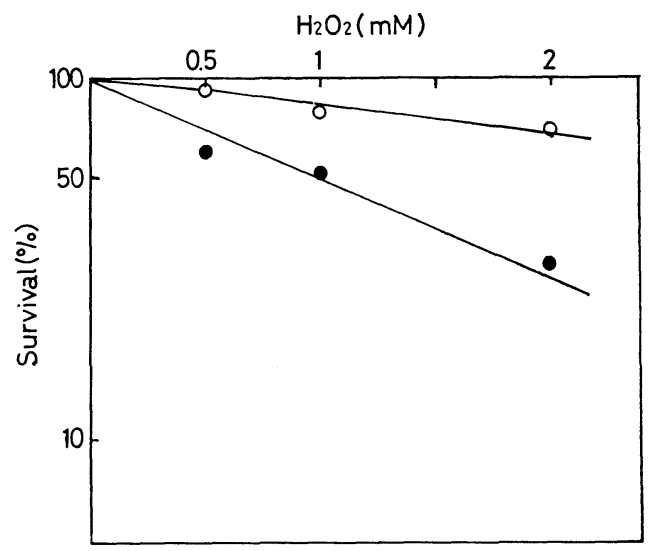

Fig. 6. Effect of methyl-viologen on survival of E. coli W3623 against $\mathrm{H}_{2} \mathrm{O}_{2}$.

Conditions of growth are as described in the legend for Fig. 4. O, methyl-viologen treated cells; $\boldsymbol{\bullet}$, control cells.

\section{Effect of $\mathrm{H}_{2} \mathrm{O}_{2}$ and $\gamma$-ray irradiation on survival}

To confirm that catalase was induced by methyl-viologen treatment, we tested the effect of $\mathrm{H}_{2} \mathrm{O}_{2}$ on the survival of cells. Figure 6 shows that cells grown in the medium with methyl-viologen added were more resistant to $\mathrm{H}_{2} \mathrm{O}_{2}$ than the control cells. It was also observed, as shown in Fig. 7, that cells in which SOD and catalse had been induced by methyl-viologen were more resistant to $\gamma$-ray irradiation under the aerobic condition.

\section{DISCUSSION}

The results show that the main damage to $E$. coli cells treated with $\mathrm{O}_{2}{ }^{-}$from outside cells was sustained by the DNA. Figure 2 shows that DNA repair-deficient mutants, polA and $\operatorname{rec} A$, were more sensitive to the treatment than the wild type strain. Figure 3 shows that this DNA damage could be repaired by rec genedependent repair, called the type III repair mechanism.

Addition of the scavenger outside cells increased the survival of cells. Catalase especially completely protected cells from death, revealing that $\mathrm{H}_{2} \mathrm{O}_{2}$ rather than $\mathrm{O}_{2}{ }^{-}$itself was the main cause of cell death. ANANTHASWAMY and EISENSTARK (23) have reported that $\mathrm{H}_{2} \mathrm{O}_{2}$ causes DNA single strand breaks. In our experiment, it is suggested that $\mathrm{O}_{2}^{-}$generated outside cells is converted to $\mathrm{H}_{2} \mathrm{O}_{2}$, which attacks DNA. However, a partial protective effect was seen when SOD was added, suggesting that the $\mathrm{OH}$ radical which is known to be produced from the reaction between $\mathrm{H}_{2} \mathrm{O}_{2}$ and $\mathrm{O}_{2}^{-}$may be involved in induction of DNA damage. This possibility may explain the experimental result that both conversion of $\mathrm{O}_{2}{ }^{-}$to $\mathrm{H}_{2} \mathrm{O}_{2}$ by SOD and elimination of $\mathrm{H}_{2} \mathrm{O}_{2}$ by catalase can protect cells from inactivation by $\mathrm{O}_{2}^{-}$. 


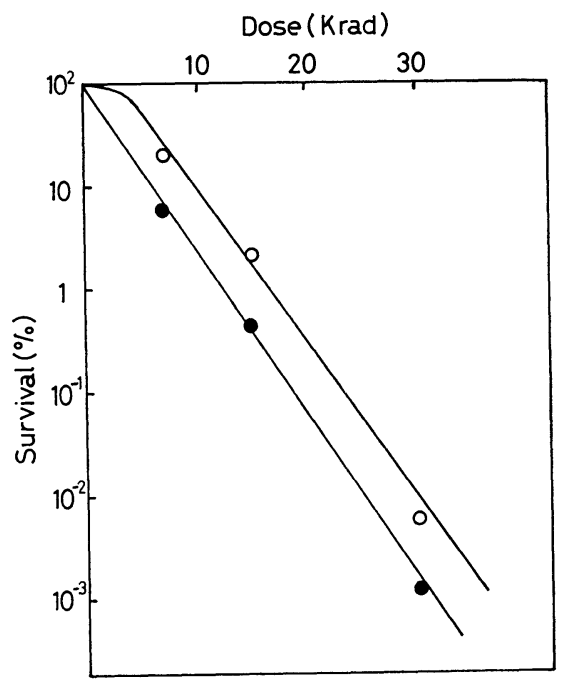

Fig. 7. Effect of methyl-viologen on survival of $E$. coli W3623 against $\gamma$-ray irradiation aerobically.

Conditions of growth are as described in the legend for Fig. 4. $\bigcirc$, methyl-viologen treated cells; $\bullet$, control cells.

Cells grown in the presence of methyl-viologen had higher levels of SOD and catalase and acquired the resistance to $\mathrm{O}_{2}{ }^{-}$generated extracellularly. These cells were also more resistant to $\mathrm{H}_{2} \mathrm{O}_{2}$ or $\gamma$-ray irradiation under the aerobic condition.

It is suggested that catalase inside cells also plays a protective role against $\mathrm{H}_{2} \mathrm{O}_{2}$. HASSAN and FRIDOVICH (24) reported that catalase- and peroxidase-deficient mutants of $E$. coli were more sensitive under a high $\mathrm{O}_{2}$-level condition than the wild type cells. Therefore, catalase and peroxidase (EC 1.11.1.7) in the cell play an important role in protecting cells from active oxygen molecules. HoLLAENDER et al. (25) did not find a protective effect of SOD against $\gamma$-ray irradiation. However, the results described in this study show that the scavenger inside cells slightly increase the survival of $\gamma$-ray irradiated cells (Fig. 7). This discrepancy may be attributable to differences in the procedure for the induction of SOD and catalase. Our result may indicate that the oxygen effect is partly explained by the toxicity of $\mathrm{H}_{2} \mathrm{O}_{2}$ produced by $\gamma$-ray irradiation in the presence of oxygen.

This work was supported in part by grants from the Nuclear Safety Research Project at the Research Center for Nuclear Science and Technology, The University of Tokyo.

\section{REFERENCES}

1) A. M. Michelson, J. M. McCord, and I. Fridovich (eds.), Superoxide and Superoxide Dismutases, Academic Press, New York (1977).

2) O. HayAishi and K. AsadA (eds.), Biochemical and Medical Aspects of Active Oxygen, Japan Sci. Soc. Press, Tokyo (1977). 
3) Ciba Foundation Symposium 65, Oxygen Free Radicals and Tissue Damage, Excerpta Medica, Amsterdam (1979).

4) A. M. Michelson and M. E. Buchingham, Biochem. Biophys. Res. Commum., 58, 1079 (1974).

5) L. W. Oberley, A. L. Lindgren, S. A. Buker, and R. H. Stevens, Radiat. Res., 68, 320 (1976).

6) H. D. Misra and I. Fridovich, Arch. Biochem. Biophys., 176, 577 (1976).

7) T. Niwa, H. Yamaguchi and K. Yano, Agric. Biol. Chem., 42, 689 (1978).

8) S. A. Goscin and I. Fridovich, Radiat. Res., 56, 565 (1973).

9) B. M. Babior, J. J. Curnutte, and R. S. Kipnes, J. Rab. Clin. Med., 85, 235 (1975).

10) H. M. Hassan and I. Fridovich, J. Bacteriol., 129, 1574 (1977).

11) H. M. Hassan and I. Fridovich, J. Biol. Chem., 252, 7667 (1968).

12) K. Asada, M. Takahashi, and M. Nagata, Agric. Biol. Chem., 38, 471 (1974).

13) J. M. MCCord and I. Fridovich, J. Biol. Chem., 244, 6049 (1969).

14) R. F. Beers, Jr. and I. W. Sizer, J. Biol. Chem., 195, 133 (1952).

15) Y. Kurono and K. Horikoshi, Agric. Biol. Chem., 37, 2565 (1973).

16) O. H. Lowry, N. J. Rosebrough, A. L. Farr, and R. J. Randall, J. Biol. Chem., 193, 265 (1951).

17) M. Nishikimi, N. A. RaO, and K. Yagi, Biochem. Biophys. Res. Commum., 46, 849 (1972).

18) R. FrIED, Biochimie, 57, 657 (1975).

19) C. D. Town, K. C. Smith, and H. S. Kaplan, Curr. Top. Radiat. Res. Q., 8, 351 (1973).

20) C. D. Town, K. C. Smith, and H. S. Kaplan, Science, 172, 851 (1971).

21) H. M. Hassan and I. Fridovich, J. Bacteriol., 132, 505 (1977).

22) H. W. Dougherty, S. J. Saowsky, and E. E. Baker, J. Biol. Chem., 253, 5220 (1978).

23) H. N. Ananthaswamy and A. Eisenstark, J. Bacteriol., 130, 187 (1977).

24) H. M. Hassan and I. Fridovich, Rev. Infect. Dis., 1, 357 (1979).

25) A. Hollaender, G. E. Stapleton, and F. L. Martin, Nature, 167, 103 (1951). 